\title{
PERMODELAN ESTIMASI POTENSI TAMBANG BATU KAPUR DARI HASIL ANALISA DATA CITRA SATELIT LANDSAT 7 ETM+ (Studi Kasus : Tambang Batu Kapur PT. Semen Gresik Persero Tbk. Pabrik Tuban)
}

\author{
Nurjannah, Yuwono \\ Program Studi Teknik Geomatika FTSP-ITS, Kampus ITS Sukolilo, Surabaya, 60111 \\ Email : yuwono@geodesy.its.ac.id
}

\begin{abstract}
Abstrak
Batu kapur merupakan salah satu bahan galian C yang banyak terdapat di Indonesia. Besarnya potensi tersebut diiringi pula dengan konsumsi batu kapur yang besar untuk memenuhi kebutuhan manusia.Begitu banyaknya hasil olahan pabrik yang membutuhkan batuan kapur menunjukkan bahwasanya peran batu kapur dalam proses industri sangatlah penting misalnya saja sebagai bahan utama pembuatan semen. Salah satu perusahaan yang melakukan eksplorasi dan penambangan batu kapur yang digunakan sebagai bahan utama pembuatan semen adalah PT. Semen Gresik (PERSERO) Tbk. Dalam menentukan estimasi potensi batu kapur perusahaan ini mengambil data dari pemetaan topografi, yaitu melalui pengukuran pada titik-titik ketinggian kawasan pertambangan batu kapur.

Dengan kemajuan teknologi dibidang penginderaan jauh, perhitungan estimasi potensi batu kapur dapat dilakukan dengan menggunakan data citra satelit Landsat 7 ETM+.Parameter yang digunakan untuk identifikasi potensi batu kapur pada penelitian ini ada 4 yaitu suhu permukaan, tutupan lahan, indeks vegetasi, dan interpretasi visual.Parameter utama yang dijadikan untuk membuat model estimasi potensi batu kapur adalah suhu permukaan tanah.Korelasi antara suhu permukaan di citra dan lapangan adalah 55,9\%. Dengan regresi linier sederhana didapatkan nilai $r^{2}=0,313$, dengan persamaan koreksi suhu permukaan antara citra dan suhu lapangan adalah suhu Citra $\left({ }^{\circ} \mathrm{C}\right)=78,23-1,233$. Suhu lapangan. Suhu di citra dan suhu lapangan memiliki hubungan yang terbalik artinya ketika suhu di lapangan tinggi maka suhu di citra rendah. Dari persamaan koreksi didapat ketika suhu batu kapur dilapangan adalah $38^{\circ} \mathrm{C}$ maka suhu di citra Landsat adalah $31,5^{\circ} \mathrm{C}$.
\end{abstract}

Kata Kunci : Batu Kapur, Tutupan Lahan, Indeks Vegetasi, Suhu Permukaan

\section{PENDAHULUAN}

Batu kapur merupakan salah satu bahan galian $C$ yang banyak terdapat di Indonesia. Pegunungan kapur di Indonesia menyebar dari barat ke timur mulai dari pegunungan di Jawa Tengah hingga ke Jawa Timur, Madura, Sumatra, dan Irian Jaya. Besarnya potensi tersebut diiringi pula dengan konsumsi batu kapur yang besar untuk memenuhi kebutuhan manusia. Secara umum segala benda yang ada di rumah dan kantor membutuhkan batuan kapur dengan fase tertentu baik langsung maupun tidak langsung, baik sebagai proses primer maupun sebagai bahan tambahan. Begitu banyaknya hasil olahan pabrik yang membutuhkan batuan kapur menunjukkan bahwa peran batu kapur dalam proses industri sangatlah penting misalnya sebagai bahan utama pembuatan semen (Haidir, 2011).
Penambangan bahan galian merupakan kegiatan dalam rangka penyediaan bahan baku untuk keperluan penambangan disegala bidang. Maka dari itu usaha pertambangan tidak lepas dari pekerjaan-pekerjaan dalam mencari bahan tambang. Salah satu hal yang terpenting dalam pekerjaan pertambangan adalah perhitungan estimasi potensi tambang. Estimasi potensi tambang berperan penting dalam menentukan jumlah kualitas, kerja produksi,cara penambangan yang dilakukan, bahkan memperkirakan waktu yang dibutuhkan oleh perusahaan dalam melakukan usaha penambangan.

Salah satu perusahaan yang melakukan eksplorasi dan penambangan batu kapur yang digunakan sebagai bahan utama pembuatan semen adalah PT. Semen Gresik (PERSERO) Tbk. PT. Dalam menentukan estimasi potensi batu kapur perusahaan ini mengambil data dari pemetaan 
topografi, yaitu melalui pengukuran pada titik-titik ketinggian kawasan pertambangan batu kapur.

Dengan kemajuan teknologi dibidang inderaja, perhitungan estimasi potensi batu kapur dapat dilakukan dengan menggunakan data citra satelit Landsat 7 ETM+. Penelitian ini diharapkan dapat memberikan kontribusi di bidang pertambangan Indonesia, karena nantinya bisa dijadikan sebagai data spasial dengan metode yang lebih cepat dan efisien dalam perhitungan estimasi potensi batu kapur tanpa mengurangi pengukuran di lapangan.

\section{METODOLOGI PENELITIAN}

\section{Lokasi Penelitian}

Lokasi penelitian tugas akhir ini mengambil daerah studi kawasan pertambangan batu kapur milik PT Semen Gresik (Persero) Tbk pabrik Tuban yang berada di desa Sumberarum kecamatan Kerek Tuban.

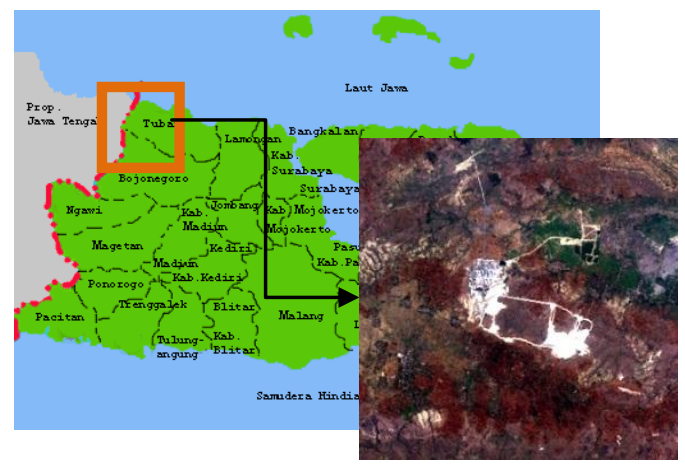

Gambar 1. Lokasi penelitian

\section{Data dan Peralatan}

1) Data

- Data pengukuran topografi tambang batu kapur Juli 2011

- Citra Landsat 7 ETM+tahun 2001tanggal akuisisi 27 Agustus 2001 path/row 118/065 dengan resolusi $30 \mathrm{~m}$

- Softcopy peta geologi lembar jatirogo skala 1: 100.000 tahun 1992 yang digunakan sebagai data pembanding untuk proses klasifikasi sebaran batuan

- Citra Landsat 7 ETM Orthometrik tahun 2000 dengan tanggal akuisisi 17 Agustus 2000 path/row 118/065

2) Peralatan

- Sistem Operasi Windows 7
- Microsoft Office 2007

- ArcGIS 10

- ENVI 4.6.1

- Matlab 7.0

- Autodesk Land Desktop 2004

- GPS Handheld

\section{Tahap Pengolahan Data}

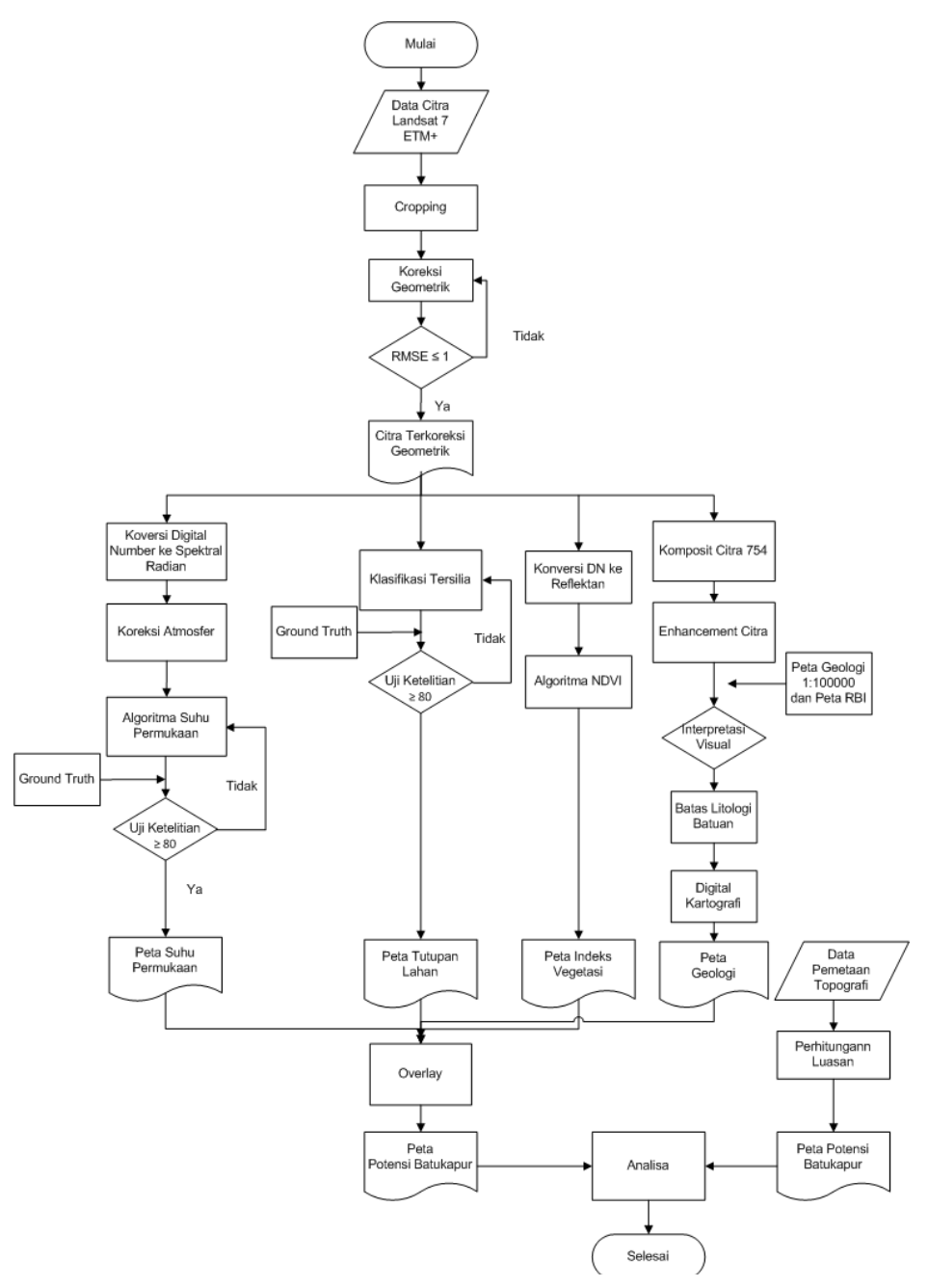

Gambar 2. Tahap Pengolahan Data

1. Citra yang digunakanadalah citra Landsat 7 ETM+ akuisisi 27 Agustus tahun 2001 dengan ketelitian citra sebesar 30 meter.

2. Pemotongan (cropping) dilakukan untuk mendapatkan citra digital yang hanya meliputi daerah penelitianyaitu kawasan tambang batu kapur PT. Semen Gresik (PERSERO) Tbk.

3. Koreksi Geometrik dilakukan dengan tujuan mereduksi kesalahan geometrik sehingga dihasilkan citra yang terkoreksi geometrik. 
Koreksi dilakukan dengan citra Landsat 7 ETM Ortho akuisisi 17 Agustus 2000 path/row 118/065. Metode yang digunakan adalah metode polynomial dengan intepolasi linear dan metode resampling nearest neighbour.

4. RMSE adalah parameter tingkat keakurasian dari proses koreksi geometrik, yaitu nilai yang dipresentasikan oleh selisih antara koordinat titik kontrol hasil transformasi dengan koordinat titik control. Pada penelitian ini RMSE yang didapatkan adalah 0,586191 dengan 13 titik yang tersebar di kawasan penelitian.

5. Citra kemudian diolah menjadi 4 peta yaitu peta suhu permukaan, tutupan lahan, indeks vegetasi dan sebaran batuan.

6. Ground Truth pada penelitian ini dilakukan dua kali yaitu ground truth untuk uji ketelitian tutupan lahan dan ground truth suhu permukaan tanah.

7. Uji ketelitian adalah proses yang dilakukan untuk melakukan pengecekan antara hasil pengolahan di citra dan pengukuran di lapangan. Uji ketelitian tutupan lahan didapatkan hasil $83,3 \%$

8. Empat peta hasil pengolahan citra di overlay untuk mendapatkan peta potensi batu kapur.

9. Data koordinat $X, Y$, dan $Z$ batu kapur bulan juli 2011 yang telah didapat harus ditransformasikan dari koordinat lokal ke UTM. Selanjutnya akan dilakukan plotting autodesk land desktop 2004 untuk menghitung luasan potensi batu kapur yang ada di PT. Semen Gresik (Persero) Tbk.

10. Overlay dalam penelitian ini dilakukan terhadap 4 peta yaitu peta suhu permukaan, peta tutupan lahan, peta indeks vegetasi, dan peta geologi hasil interpretasi visual. Peta suhu permukaan adalah parameter utama untuk membuat model identifikasi potensi batu kapur, sedangkan 3 peta yang lain hanya menjadi informasi pendukung.

11.Tahap Analisa

Analisa dilakukan pada suhu permukaan hasil pengolahan citra dan suhu permukaan di lapangan. Selanjutnya dengan regresi sederhana akan dibuat model identifikasi potensi batu kapur.

\section{HASIL DAN PEMBAHASAN}

\section{Hasil Peta}

1. Peta Suhu Permukaan

Lokasi penelitian didominasi oleh suhu permukaan dengan kisaran suhu $34^{\circ} \mathrm{C}-36^{\circ} \mathrm{C}$ seluas 3,838 hektar dan kisaran suhu $32^{\circ} \mathrm{C}-34^{\circ} \mathrm{C}$ seluas 3,359.7 hektar. Berdasarkan peta geologi skala 1: 100.000 lembar jatirogo dapat dilihat bahwa lokasi penelitian didominasi oleh formasi paciran dengan satuan batu gamping pejal dan batu gamping dolomitan. Jika demikian, berdasarkan tabel emisivitas maka suhu permukaan yang mendominasi seharusnya adalah suhu $38^{\circ} \mathrm{C}$, namun pada hasil pengolahan citra band 61 suhu permukaan $38^{\circ} \mathrm{C}$ hanya 319,7 hektar. Oleh karena itu hasil pengolahan citra yang ada perlu dilakukan koreksi dengan melakukan pengecekan lapangan.

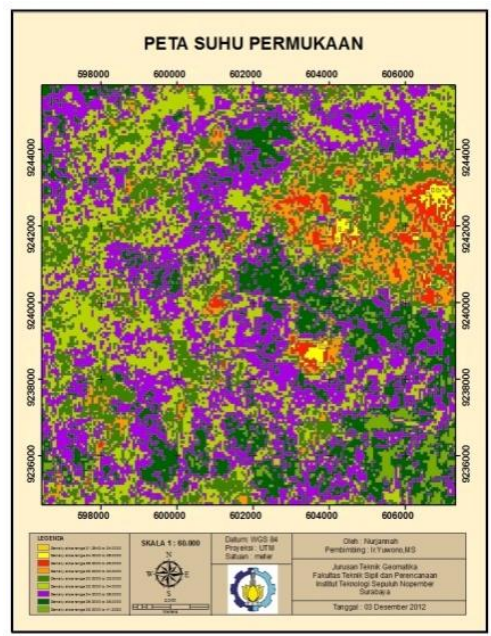

Gambar 3. Peta Suhu Permukaan

2. Peta Tutupan Lahan

Pada lokasi penelitian didapatkan 4 tipe tutupan lahan yaitu permukiman, sawah, air, semak belukar, ladang/tegalan. 


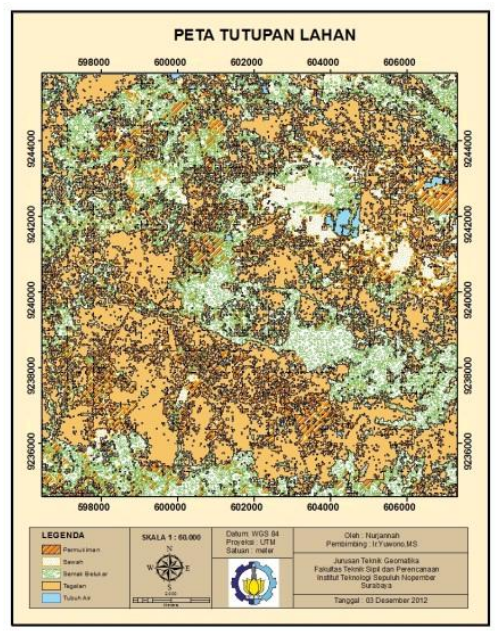

Gambar 4. Peta Tutupan Lahan

Tabel 2. Luasan Tutupan Lahan

\begin{tabular}{llc}
\hline \hline No & Jenis Tutupan Lahan & Luas $(\mathrm{Ha})$ \\
\hline \hline 1 & Permukiman & 2521,9 \\
2 & Sawah & 1946,1 \\
3 & Tubuh Air & 106,9 \\
4 & Semak Belukar & 3031,4 \\
5 & Ladang/Tegalan & 5163,1 \\
& Jumlah & 12769,4 \\
\hline \hline
\end{tabular}

Berdasarkan parameter penutup lahan, maka untuk mengidentifikasi potensi batu kapur tutupan lahan yang diperkiraan terdapat batu kapur adalah tutupan lahan ladang dan semak belukar.

\section{Peta Indeks Vegetasi}

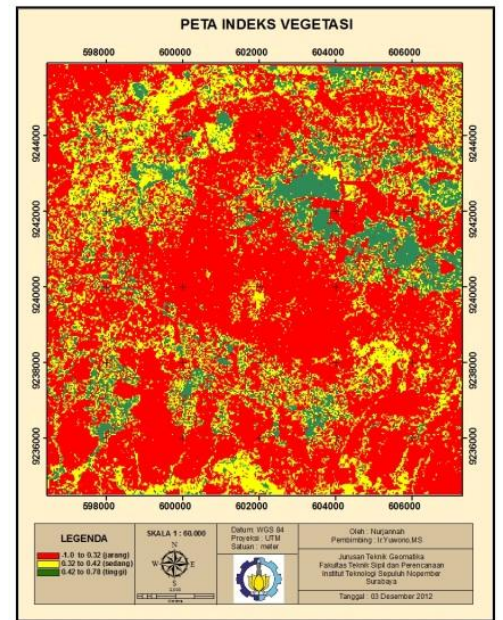

Gambar 5. Peta indeks vegetasi

Jika ditinjau dari parameter kerapatan vegetasi, menurut Syaeful dalam bahri menyatakan bahwa salah satu syarat terbentuknya kawasan karst (dengan dominasi batu kapur dan dolomit) adalah memiliki vegetasi penutup lahan dengan kerapatan tinggi. Namun ketika dilakukan pengolahan di citra dan pengecekan dilapangan di dapatkan hasil bahwa indeks vegetasi yang ada di lokasi tambang batu kapur tersebut masuk dalam tipe kerapatan vegetasi yang jarang (range -1 sampai 0,32). Hal tersebut dikarena lokasi tambang yang ada sudah berubah menjadi dari semak belukar menjadi ladang/tegalan. Range -1 sampai 0.32 memiliki luasan paling besar dalam pembagian tipe indeks vegetasi yaitu 8374,6 hektar.

\section{Interpretasi Visual}

Berdasarkan hasil interpretasi visual,peta geologi lembar jatirogo, dan pengecekan dilapangan didaptkan hasil bahwa batuan yang ada di lokasi penelitian antara lain :

1. Anggota ngrayong, formasi tuban (Tmtn) Batupasir kuarsa berselingan batugamping dan batulempung.Dalam kenampakan di citra memiliki warna biru cerah dengan selingan warna kuning dan orange. Formasi ini memiliki luasan 1150,7 hektar.

2. Formasi paciran (Tpp)

Batugamping pejal, dan batugamping dolomitan.Dalam kenampakan di citra memiliki warna biru cerah dan diselingi warna biru tua. Formasi ini memiliki luasan 8225,1 hektar.

3. Aluvium (Qa)

Pasir, lempung, lanau, dan kerikil.Dalam kenampakan di citra memiliki warna merah diselingi warna biru tua.Formasi ini memiliki luasan 3265,7 hektar.

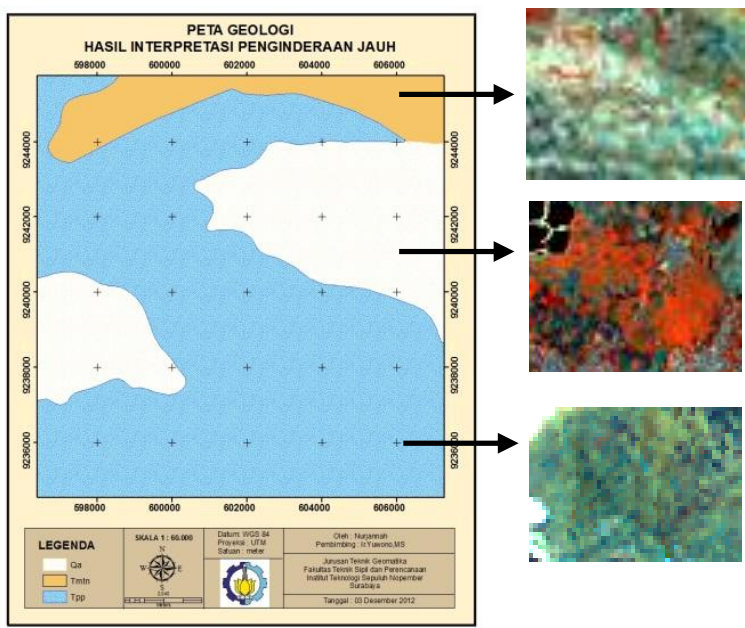

Gambar 6. Peta geologi hasil interpretasi

Dari hasil pengolahan citra diketahui bahwa tambang batu kapur berada pada formasi paciran (tpp) dengan satuan batuan satuan batugamping 
pejal, dan batugamping dolomitan. Formasi ini memiliki luasan 8225,1 hektar.

\section{Pengolahan Data Koordinat}

Pengolahan data koordinat $x, y, z$ dilakukan dengan menggunakan menggunakan Autocad Land Dekstop 2004. Semua koordinat yang ada akan diolah untuk selanjutnya didapatkan luasan tambang batu kapur di PT. Semen Gresik Persero, Tbk. Dari hasil perhitungan dalam Autocad didapatkan bahwa luasan tambang batu kapur yaitu 866,9 hektar.

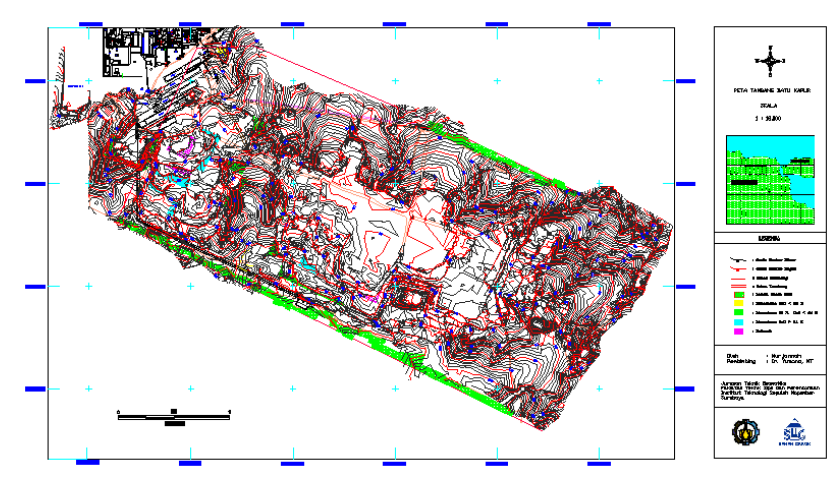

Gambar 7. Peta Tambang Batu Kapur

\section{Analisis}

1. Uji Ketelitian Klasifikasi Tutupan Lahan Pengukuran suhu permukaan ini dilakukan dengan menggunakan termometer yang ditancapkan ke dalam tanah.Pengukuran dilakukan dengan mengambil 20 sampel yang menyebar pada lokasi yang berdasarkan peta geologi terdapat potensi batu kapur.Pengukuran dilakukan pada tanggal 20 Juli 2013 pukul 12.00 14.00 WIB.

Uji korelasi ini dilakukan dengan membandingkan suhu permukaan di citra dengan hasil ground truth. Hal ini dilakukan untuk mengetahui sejauh mana korelasi atau kedekatan suhu permukaan hasil pengolahan citra dengan hasil lapangan.Ketika dilakukan uji korelasi antara suhu permukaan di citra dan lapangan didapatkan nilai 0,559 dapat diartikan bahwa keeratan hubungan antara suhu citra dan suhu di lapangan adalah $55,9 \%$
2. Permodelan Estimasi Potensi Batu Kapur Untuk membuat model estimasi potensi batu kapur dilakukan dengan metode regresi linier sederhana.Berikut ini grafik regresi antara data lapangan dan hasil pengolahan citra.

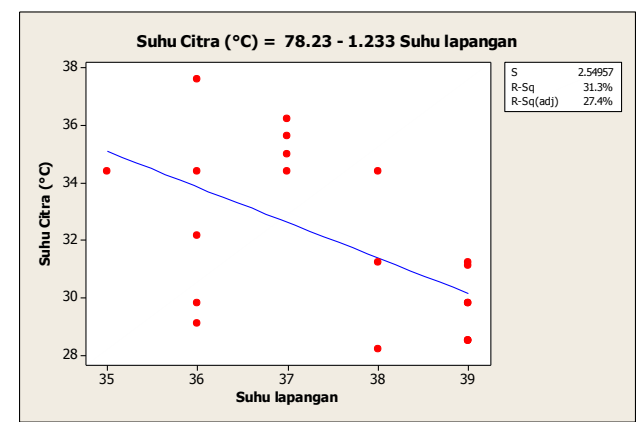

Gambar 8. Grafik regresi suhu pengolahan citra band 61 dan data lapangan

Dengan regresi linier sederhana didapatkan nilai $r^{2}=0,313$, seperti pada gambar 4.22. Dengan persamaan koreksi suhu di citra sebagai berikut :

Suhu Citra $\left({ }^{\circ} \mathrm{C}\right)=78,23-1,233$. Suhu Lapangan

Nilai $r^{2}=0,313$ bermakna bahwa 0,313 atau 31,3\% diantara keragaman total nilai Citra (y)dapat dijelaskan oleh hubungan liniernya dengan nilai lapangan $(x)$. Dari persamaan koreksi diatas didapat ketika suhu batu kapur dilapangan untuk identifikasi adalah $38^{\circ} \mathrm{C}$ maka suhu di citra adalah $31,5^{\circ} \mathrm{C}$.

Berikut ini distribusi suhu permukaan tanah hasil pengukuran lapangan dan hasil pengolahan citra.

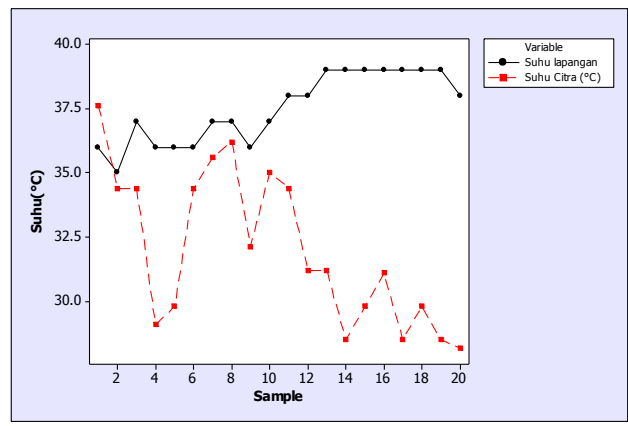

Gambar 9. Pola Distribusi suhu permukaan di citra dan Data Lapangan

Grafik di atas menunjukan pola distibusi suhu permukaan hasil pengolahan citra dengan hasil pengukuran lapangan.Dari grafik tersebut dapat 
disimpulkan bahwa antara hasil pengolahan citra dan data lapangan hubungan yang terbalik.

Dari hasil uji korelasi dapat didapatkan bahwa keeratan hubungan antara data lapangan dan data citra hanya $55,9 \%$, itu artinya data citra yang ada tidak bisa dijadikan patokan identifikasi untuk estimasi potensi. Jika akan mencari estimasi batu kapur harus menggunakan persamaan koreksi hasil regresi. Koreksi yang ada dikarenakan suhu yang direkam oleh citra bisa saja suhu yang berada di atas vegetasi dan bukan suhu pada permukaan tanahnya. Indeks vegetasi juga mempengaruhi suhu permukaan karena semakin rapat suatu vegetasi maka suhu yang terekam akansemakin dingin karena tertutup oleh vegetasi yang ada diatasnya. Analisa lain karena terlalu banyak faktor yang mempengaruhi seperti yang telah dijelaskan pada bab 2, faktor yang mempengaruhi suhu permukaan tanah ada 2 yaitu faktor luar dan faktor dalam. Yang dimaksud dengan faktor luar adalah radiasi matahari, awan, curah hujan, angin, kelembapan udara. Faktor dalamnya adalah faktor tanah, struktur tanda, kadar air tanah, kandungan bahan organik, dan warna tanah. Banyaknya faktor yang mempengaruhi suhu permukaan akan sulit dijadikan sebagai patokan identifikasi jenis batuan dan harus dilakukan penelitian yang cukup dalam dari waktu ke waktu.

Identifikasi potensi batu kapur dari parameter tutupan lahan tidak cukup dengan menggunakan satu jenis tipe tutupan lahan karena pada awal terbentuknya kawasan karst tutupan lahan berupa semak belukar telah berubah menjadi ladang/tegalan pada sebagian luasannya. Yang perlu diperhatikan pada parameter ini adalah proses perubahan tutupan lahan yang terjadi dari tahun ke tahun sehingga bisa membantu proses identifikasi potensi yang ada. Adanya peta geologi lokasi penelitian akan sangat membantu identifikasi potensi batu kapur.

Hasil analisa yang ada menunjukkan bahwa parameter indeks vegetasi berkaitan dengan parameter tutupan lahan.Tutupan lahan ladang/tegalan memiliki nilai yang lebih rendah dibandingkan dengan tutupan lahan semak belukar dan sawah. Ladang/tegalan memiliki nilai indeks vegetasi berkisar antara -1 sampai 0,32 sedangkan semak belukar berkisar antara 0,32 sampai 0,42 dan sawah antara 0,42 sampai 1 .

Litologi batuan pada lokasi penelitian adalah formasi tpp dengan satuan batugamping pejal, dan batugamping dolomitan. Peta geologi sebagai data sekunder untuk membantu proses interpretasi visual pada citra Landsat 7 ETM+ kombinasi band 457. Untuk membantu interpretasi visual juga bisa didukung oleh data DEM dan peta RBI untuk menunjukkan adanya ketinggian, cekungan tertutup dan lembah kering yang merupakan ciri dari adanya kawasan karst.

\section{KESIMPULAN DAN SARAN}

Berdasarkan hasil penelitian maka didapatkan beberapa kesimpulan akhir dari penelitian ini, yaitu:

1. Korelasi antara suhu permukaan di citra dan lapangan adalah 55,9\%.

2. Persamaan koreksi hasil regresi adalah Suhu Citra $\left({ }^{\circ} \mathrm{C}\right)=78,23-1,233$.Suhu Lapangan. Jika suhu batu kapur di lapangan untuk identifikasi adalah $38^{\circ} \mathrm{C}$ maka suhu di citra adalah $31,5^{\circ}$ C.

3. Penutup lahan yang ada di daerah penelitian memiliki 5 jenis tutupan lahan, yaitu permukiman, sawah, air, ladang/tegalan, dan semak belukar. Batu kapur ditemukan pada tutupan lahan semak belukar dan ladang/tegalan.

4. Nilai Indeks vegetasi di daerah penelitian berkisar antara $-1,0000$ sampai 0,7802 , sedangkan untuk tambang batu kapur memiliki tipe indeks vegetasi jarang dengan nilai kisaran -1,0000 sampai 0,32.

5. Formasi batuan yang ada yaitu anggotan ngrayong formasi tuban (Tmtn), formasi paciran (Tpp), dan Aluvium (Qa). Formasi batuan yang ada di tambang batu kapur adalah formasi paciran dengan satuan batu gamping pejal dan batu gamping dolomitan.

\section{DAFTAR PUSTAKA}

Barsi, Julia A., John L. Barker, John R. Schott, (2003), "An Atmospheric Correction Parameter Calculator for SingleThermal Band Earth-Sensing Instrument", IEEE.

Danoedoro, P. 1996. Pengolahan Citra Digital : Teori dan Aplikasi dalam Bidang Penginderaan 
Jauh. Yogyakarta: Fakultas Geografi Universitas Gadjah Mada.

Desi, 2011.Aplikasi penginderaan jauh untuk menduga suhu Permukaan dan udara di lahan gambut dan mineral Dengan menggunakan metode neraca energi (area studi : sampit, kalimantan tengah). Departemen Geofisika dan Meteorologi, FMIPA-IPB, Bandung

Ford, D. and Williams, P. 1992. Karst Geomorphology and Hydrology, Chapman and Hall, London

Haidir, S. 2011. Uji Kemurniaan Komposisi Fasa Batu Kapur Tuban dengan Analisis Rietveld Data Difraksi Sinar-X, Tugas Akhir, Jurusan Fisika FMIPA-ITS, Surabaya.

Hariyanto, T. 2006. Penggunaan Citra Digital Penginderaan Jauh untuk Perhitungan Volume Lumpur di Lokasi Semburan Lumpur PT.Lapindo Brantas Porong Sidoarjo, Prosiding Pertemuan IImiah Tahunan III, Teknik Geomatika FTSP-ITS, Surabaya.

Lillesand, Thomas, M., dan Ralph, W., Kiefer, 1990, "Penginderaan Jauh dan Interpretasi Citra". , Yogyakarta : Gadjah Mada University Press.

Lillesand T.M., and Kiefer R.W. 1994. Remote Sensing and Image Interpretation. Second Edition. New York: John Willey \& Sons.

Maryantika, N. 2011. Analisa Perubahan Vegetasi Ditinjau dari Tingkat Ketinggian dan Kemiringan Lahan Menggunakan Citra Satelit Landsat dan SPOT 4, Teknik Geomatika FTSP-ITS, Surabaya

Mustika, A. 2012. Perhitungan Volume Semburan dan Sebaran Lumpur Sidoarjo dengan Citra Ikonos Multitemporal 2011, Tugas Akhir, Teknik Geomatika FTSP-ITS, Surabaya

Noor, K. 2008. Pemetaan Prediksi Lokasi Mineral Uranium dengan Citra Landsat 7 ETM+, Teknik Geomatika FTSP-ITS, Surabaya
Prahasta, Eddy. 2008. Remote Sensing Praktis Penginderaan Jauh dan Pengolahan Citra Dijital dengan Perangkat Lunak ER Mapper. Bandung: Informatika.

Purwadhi, Sri Hardiyanti.2001. Interpretasi Citra Digital. Jakarta: PT Gramedia Widiasarana

Shilu, T. 2008. Using Remote Sensing and GIS Techniques in Spatial Information Monitoring of Coal Refuse Disposal Piles.The International Archives of the Photogrammetry, Remote Sensing and Spatial Information Sciences. Vol. XXXVII. Part B8. Beijing

Sofani, R. 2011.Deliniasi Prospek Panas Bumi Daerah Tiris Probolinggo Dan Sekitarnya Dengan Analisa Citra Satelit Landsat 7 Etm+, Fisika FMIPA-ITS, Surabaya

Sucipto, E. 2007. Hubungan Pemaparan Partikel Debu pada Pengolahan Batu Kapur Terhadap Penurunan Kapasitas Fungsi Paru, Program Magister IImu Lingkungan-UNDIP, Semarang

Sutanto. 1994. Penginderaan Jauh. Jilid 2. Yogyakarta : Gadjah Mada University Press.

Thoha, Achmad Siddik. 2008. Karakteristik Citra Satelit. Medan: Departemen Kehutanan Fakultan Pertanian Universitas Sumatra Utara

Yuwono. 2004. Pendidikan dan Pelatihan (Diklat) Teknik Pengukuran

Undang-Undang RI No.4 Tahun 1992 tentang Permukiman dan Perumahan. Jakarta : Kantor Sekretariat Negara

Yuwono. 2004. "Pendidikan dan Pelatihan (DIKLAT) Teknis Pengukuran dan Pemetaan Kota". Surabaya: Teknik Geomatika Institut Teknologi Sepuluh Nopember

Zhou, Q. Lees, B. Tang, G. 2008. “Advances in Digital Terrain Analysis". Berlin: Springer-Verlag Berlin Heidelberg 